\title{
Mass yields of secondary organic aerosols from the oxidation of $\alpha$-pinene and real plant emissions
}

\author{
L. Q. Hao ${ }^{1}$, S. Romakkaniemi ${ }^{1}$, P. Yli-Pirilä ${ }^{2}$, J. Joutsensaari ${ }^{1}$, A. Kortelainen $^{1}$, J. H. Kroll ${ }^{4}, 6$, P. Miettinen ${ }^{1}$, \\ P. Vaattovaara ${ }^{1}$, P. Tiitta ${ }^{1}$, A. Jaatinen ${ }^{1}$, M. K. Kajos ${ }^{3}$, J. K. Holopainen ${ }^{2}$, J. Heijari ${ }^{2,9}$, J. Rinne ${ }^{3}$, M. Kulmala ${ }^{3}$, \\ D. R. Worsnop ${ }^{1,3,4,5}$, J. N. Smith ${ }^{1,7,8}$, and A. Laaksonen ${ }^{1,5}$ \\ ${ }^{1}$ Department of Applied Physics, University of Eastern Finland, Kuopio 70211, Finland \\ ${ }^{2}$ Department of Environmental Sciences, University of Eastern Finland, Kuopio 70211, Finland \\ ${ }^{3}$ Department of Physics, University of Helsinki, Helsinki 00014, Finland \\ ${ }^{4}$ Aerodyne Research, Inc., Billerica, MA 08121-3976, USA \\ ${ }^{5}$ Finnish Meteorological Institute, Helsinki 00101, Finland \\ ${ }^{6}$ Department of Civil and Environmental Engineering, Massachusetts Institute of Technology, Cambridge MA, USA \\ ${ }^{7}$ Atmospheric Chemistry Division, National Center for Atmos. Res., 1850 Table Mesa Dr., Boulder, CO 80305, USA \\ ${ }^{8}$ Finnish Meteorological Institute, Kuopio 70211, Finland \\ ${ }^{9}$ Kotka Maritime Research Centre, Kotka 48310, Finland
}

Received: 19 October 2010 - Published in Atmos. Chem. Phys. Discuss.: 24 November 2010

Revised: 1 February 2011 - Accepted: 8 February 2011 - Published: 16 February 2011

\begin{abstract}
Biogenic volatile organic compounds (VOCs) are a significant source of global secondary organic aerosol (SOA); however, quantifying their aerosol forming potential remains a challenge. This study presents smog chamber laboratory work, focusing on SOA formation via oxidation of the emissions of two dominant tree species from boreal forest area, Scots pine (Pinus sylvestris L.) and Norway spruce (Picea abies), by hydroxyl radical $(\mathrm{OH})$ and ozone $\left(\mathrm{O}_{3}\right)$. Oxidation of $\alpha$-pinene was also studied as a reference system. Tetramethylethylene (TME) and 2-butanol were added to control $\mathrm{OH}$ and $\mathrm{O}_{3}$ levels, thereby allowing SOA formation events to be categorized as resulting from either $\mathrm{OH}-$ dominated or $\mathrm{O}_{3}$-initiated chemistry. SOA mass yields from $\alpha$-pinene are consistent with previous studies while the yields from the real plant emissions are generally lower than that from $\alpha$-pinene, varying from $1.9 \%$ at an aerosol mass loading of $0.69 \mu \mathrm{g} \mathrm{m}^{-3}$ to $17.7 \%$ at $26.0 \mu \mathrm{g} \mathrm{m}^{-3}$. Mass yields from oxidation of real plant emissions are subject to the interactive effects of the molecular structures of plant emissions and their reaction chemistry with $\mathrm{OH}$ and $\mathrm{O}_{3}$, which
\end{abstract}

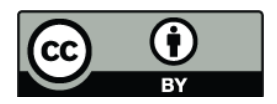

Correspondence to: L. Q. Hao (hao.liqing@uef.fi) lead to variations in condensable product volatility. SOA formation can be reproduced with a two-product gas-phase partitioning absorption model in spite of differences in the source of oxidant species and product volatility in the real plant emission experiments. Condensable products from $\mathrm{OH}$-dominated chemistry showed a higher volatility than those from $\mathrm{O}_{3}$-initiated systems during aerosol growth stage. Particulate phase products became less volatile via aging process which continued after input gas-phase oxidants had been completely consumed.

\section{Introduction}

The largest uncertainties in predicting anthropogenic influences on climate are associated with global aerosol burdens. One of the most significant global contributions of aerosol is secondary organic aerosol (SOA), which is formed when the atmospheric oxidation products of volatile organic compounds (VOCs) undergo gas to particle conversion. On a global scale, biogenic VOC (BVOC) emissions contribute an overwhelming fraction of $90 \%$ of the overall VOC emissions (Guenther et al., 1995), which underscores the importance of BVOC as a significant source of SOA.

Published by Copernicus Publications on behalf of the European Geosciences Union. 
The traditional model estimates of the global biogenic SOA flux range from 25 to $210 \mathrm{TgC} \mathrm{yr}^{-1}$ to the atmosphere (Hallquist et al., 2009). Field observations usually find higher SOA burdens than predicted by the current global aerosol models (e.g. Hallquist et al., 2009). It has been generally accepted that some unrecognized hydrocarbons are missing from these models. Recent studies have also focused on uncertainties in experimental variables for determining SOA mass. These include the initial hydrocarbon level (e.g. Shilling et al., 2008; Presto and Donahue, 2006), $\mathrm{NO}_{\mathrm{x}}$ level (e.g. $\mathrm{Ng}$ et al., 2007; Presto et al., 2005), oxidant species (e.g. Fry et al., 2009; Cai and Griffin, 2006; Griffin et al., 1999; Hoffmann et al., 1997), seed aerosol (e.g. Kroll et al., 2007; Pathak et al., 2007; Chan et al., 2007; Cocker et al., 2001), temperature (e.g. von Hessberg, et al., 2009; Saathoff et al., 2009; Pathak et al., 2007), relative humidity (RH) (e.g. von Hessberg, et al., 2009; Cocker et al., 2001; Seinfeld et al., 2001), UV intensity (e.g. Presto et al., 2005) and inorganic acid (e.g. Northcross and Jang, 2007; Kleindienst et al., 2006).

Most parameters used in modeling SOA mass loadings are based on observations from laboratory chambers. In these experiments, a single VOC compound is commonly used and individual mass yields are summed in order to model SOA from multiple species. The extension of single compound yields for the estimation of real SOA may miss the contribution of unknown BVOCs to SOA formation. This may be especially true for chemically complex aerosol formed from BVOC oxidation. In order to mimic more realistic atmospheric conditions, recent studies have been carried out to investigate SOA formation using direct biogenic emissions in the laboratory, varying from macroalgae (McFiggans et al., 2004), herbaceous plant white cabbage (Joutsensaari et al., 2005; Pinto et al., 2007) to the woody plant, oak and loblolly pine (Lang-Yona et al., 2010; VanReken et al., 2006) and silver birch, Scots pine and Norway spruce (Mentel et al., 2009; Hao et al., 2009; Kiendler-Scharr et al., 2009a, b; Vaattovaara et al., 2009; Virtanen et al., 2010). Most of these studies focused on the phenomenon of new particle formation, rarely reporting SOA mass yields (Mentel et al., 2009; Lang-Yona et al., 2010).

Here we present results from chamber studies of new particle formation using direct BVOC emissions of living trees. Scots pine (Pinus sylvestris L.) and Norway spruce (Picea abies) were selected as the dominant tree species in the European boreal forest area (Manninen et al., 1998; Christensen et al., 2000). Both $\mathrm{O}_{3}$ and $\mathrm{OH}$ were used as oxidants in the controlled conditions of these experiments. Similar experiments were conducted with $\alpha$-pinene as a reference. Our motivation was to evaluate mass yields of SOA derived from oxidation of VOC mixtures emitted from real plants, rather than individual precursors used to be applied in most previous studies. This approach is expected to give more realistic, quantitative yields, which can then be incorporated in global aerosol models.

\section{Methods}

The plant experiments were performed in the Kuopio aerosol research chamber during 12-26 October 2007. The experimental systems have been described previously in Hao et al. (2009). A short description of the facility and experimental procedure is presented here. The facility consists of a $6 \mathrm{~m}^{3}$ rectangular Teflon ${ }^{\text {TM }}$ FEP film chamber and a biogenic emission enclosure. Prior to each experiment, the chamber is continuously flushed overnight with laboratory compressed clean air and exposed to high level ozone concentration $(\sim 2 \mathrm{ppm})$ the following morning. After this cleaning procedure, air was bubbled through purified water and introduced into the chamber with clean dry air to adjust chamber relative humidity (RH). Then two trial plants were placed into the emission enclosure and VOCs were emitted under irradiation from six lamps (24 W, Lival Shuttle Plus, Lival Oy, Sipoo, Finland). Another clean air flow transported plant emissions from the plant enclosure into the chamber. SOA formation events were categorized according to whether the reaction is hydroxyl radical $(\mathrm{OH})$ reaction-dominated or ozone $\left(\mathrm{O}_{3}\right)$-initiated chemistry. In the $\mathrm{OH}$-dominated cases, tetramethylethylene (TME; 99+\%, Aldrich) was added to increase the $\mathrm{OH}$ levels (Lambe et al., 2007). As described in Hao et al. (2009), $\mathrm{O}_{3}$-initiated chemistry includes three $\mathrm{OH}+\mathrm{O}_{3}$ simultaneously initiated experiments in which the contribution fraction from ozonolysis reactivity is more than $50 \%$; and one ozonolysis experiment where 2-butanol was added as an $\mathrm{OH}$ scavenger. The 2-butanol concentration was $\sim 600$ times higher than that of the terpenes so that the reaction rate of $\mathrm{OH}$ with the scavenger exceeded that of $\mathrm{OH}$ with the parent hydrocarbons by a factor of 100 (Keywood, et al., 2004; Docherty et al., 2003). In both sets of experiments, ozone enriched air (50-800 ppb) was introduced into the chamber at a flow $40 \mathrm{~L} \mathrm{~min}^{-1}$ following of VOC precursor additions. Ozone injection marked the start of each experiment. After addition of BVOCs and oxidants, the inlet flow was turned off and the chamber was operated in batch-mode; i.e., the chamber was gradually emptied by sample flows to the instruments. In all cases SOA was formed under dark conditions. Chamber temperature varied around $25 \pm 2{ }^{\circ} \mathrm{C}$ with chamber $\mathrm{RH}$ at $35 \pm 5 \%$ (Table 1). Nine SOA formation events were selected in the present study. We employed $\alpha$-pinene as model biogenic compound and emissions from two dominant tree species from the boreal forest, Scots pine and Norway spruce, as parent precursors, respectively, in the chamber. In five experiments, we included a second ozone addition in order to achieve a broader range of aerosol mass loadings.

Rapid changes of chemical composition and concentrations in both gas- and particulate phases in the chamber were well characterized. The time evolution of VOC precursors was measured with an on-line proton transfer reaction mass spectrometer (PTR-MS, Ionicon Analytik GmbH) (Lindinger et al., 1998; de Gouw and Warneke, 2007), 
Table 1. Initial conditions of chamber operation ( $P, S$ and $R$ codes are for Scots pine, Norway spruce and $\alpha$-pinene, respectively).

\begin{tabular}{|c|c|c|c|c|c|c|c|c|c|c|c|}
\hline \multirow{2}{*}{$\begin{array}{l}\text { Exp. } \\
\text { No. }\end{array}$} & \multirow{2}{*}{$\begin{array}{l}\text { Parent } \\
\text { Precursor }\end{array}$} & \multirow{2}{*}{$\begin{array}{l}\text { TME } \\
(\mathrm{ppb})\end{array}$} & \multicolumn{4}{|c|}{ First $\mathrm{O}_{3}$ addition } & \multicolumn{5}{|c|}{ Second $\mathrm{O}_{3}$ addition } \\
\hline & & & Inlet $^{\mathrm{a}}$ & Duration $^{\mathrm{b}}$ & {$\left[\mathrm{O}_{3}\right]^{\mathrm{c}}$} & {$[\mathrm{OH}]^{\mathrm{d}}$} & Inlet $^{\mathrm{a}}$ & Start(min) & Duration $^{\mathrm{b}}$ & {$\left[\mathrm{O}_{3}\right]^{\mathrm{c}}$} & {$[\mathrm{OH}]^{\mathrm{d}}$} \\
\hline R1024 & $\alpha$-pinene & - & 200 & 40 & 30.5 & 1.03 & - & - & - & - & - \\
\hline P1012 & Pine & 118 & 200 & 25 & 4.15 & 1.07 & 200 & 55 & 25 & 15.1 & 1.85 \\
\hline P1023 & Pine & 342 & 200 & 75 & 5.17 & 1.79 & - & - & - & - & - \\
\hline P1025 & Pine & 984 & 200 & 75 & $\sim 0$ & $<0.19$ & 800 & 80 & 30 & 17.8 & 3.32 \\
\hline P1022 & Pine & - & 200 & 13 & 20.7 & 0.33 & - & - & - & - & - \\
\hline P1026 & Pine & 2-butanol, 54ppm & 60 & 30 & 6.17 & 0.0036 & 200 & 85 & 30 & 37.4 & 0.012 \\
\hline S1015 & Spruce & - & 50 & 20 & 5.5 & 0.08 & 50 & 70 & 20 & 9.5 & 0.10 \\
\hline S1017 & Spruce & - & 50 & 25 & 5.6 & 0.10 & 200 & 119 & 60 & 76.0 & 0.56 \\
\hline S1019 & Spruce & 1285 & 200 & 80 & 0.2 & $<0.2$ & 800 & 80 & 40 & 19.3 & 3.77 \\
\hline
\end{tabular}

a Ozone concentration at inlet of chamber (ppb);

$\mathrm{b}$ Duration of ozone addition into the chamber (min);

${ }^{\mathrm{c}}$ Measured maximum $\mathrm{O}_{3}$ concentration inside the chamber (ppb);

${ }^{\mathrm{d}}$ Modeled maximum $\mathrm{OH}$ concentration inside the chamber (molecules $\mathrm{cm}^{-3}, \times 10^{6}$ ).

supplemented with results from off-line measurements by a gas chromatography-mass spectrometer (GC-MS, GC model 6890/MSD 5973, Hewlett-Packard) (Vuorinen et al., 2004). Particle size distributions and volume concentration were measured by a Fast Mobility Particle Sizer (FMPS) spectrometer (model 3091; TSI) and an Aerodyne QuadrupoleAerosol Mass Spectrometer (Q-AMS) (Jayne et al., 2000; Canagaratna et al., 2007), respectively. Chemical composition of the formed particles was measured directly with Q-AMS and indirectly using a Volatility Tandem Differential Mobility Analyzer (V-TDMA) (Joutsensaari et al., 2001; Tiitta et al., 2010). The V-TDMA sequentially directs size selected aerosol (30 and $50 \mathrm{~nm}$ ) through three volatilization tubes at controlled temperature $\left(50^{\circ} \mathrm{C}, 150^{\circ} \mathrm{C}\right.$ and $280^{\circ} \mathrm{C}$ ). Volatile compounds evaporate from the particles in the heated tube and resulting size distributions are measured using a differential mobility particle sizer. Aerosol volatility is presented, expressed as the volatility growth factor (VGF), the ratio of diameter of particle size after evaporation $\left(D_{\text {eva }}\right)$ to the original sampled diameter $\left(D_{\text {ori }}\right)$ :

$\mathrm{VGF}=D_{\text {eva }} / D_{\text {ori }}$.

Other routine measurements included $\mathrm{O}_{3}$ (model 1008-RS; DASIBI Environmental Corporation, Glendale, CA), $\mathrm{NO}_{\mathrm{x}}$ (model AC 30M; Environment S.A.), $\mathrm{SO}_{2}$ (model AF21M; Environment S.A.) and RH/Temperature transmitter (model Y50; Vaisala, Finland).

Measured aerosol volume concentrations were converted to mass loading for aerosol mass yield calculations by determining aerosol densities ( $\rho_{\text {eff }}$ ) from parallel measurements of size distributions with FMPS and Q-AMS. Density is determined from the ratio of vacuum aerodynamic diameter $\left(D_{\mathrm{va}}\right)$ to mobility diameter $\left(D_{\mathrm{m}}\right)$ multiplied by unit density
( $\rho_{\mathrm{o}}$, defined as $1 \mathrm{~g} \mathrm{~cm}^{-3}$ ) (DeCarlo et al., 2004; Bahreini et al., 2005).

$\rho_{\text {eff }}=\rho_{\mathrm{o}} \frac{D_{\mathrm{va}}}{D_{\mathrm{m}}}$

Measured densities in this study are $1.34 \mathrm{~g} \mathrm{~cm}^{-3}$ for Scots pine SOA (P1012, P1023, P1022, P1025; see Table 1), $1.38 \mathrm{~g} \mathrm{~cm}^{-3}$ for ozonolysis-dominated Scots pine SOA (P1026) and $1.40 \mathrm{~g} \mathrm{~cm}^{-3}$ for Norway spruce $/ \alpha$-pinene SOAs (S1015, S1019, R1024), respectively.

\subsection{Aerosol wall loss corrections}

An important factor to consider in any chamber study is the effect of aerosol losses to the walls on measured concentrations. To address wall loss deposition, a correction method developed in previous studies (Presto and Donahue, 2006; Pathak et al., 2007) was employed. It is assumed that the wall loss rate is first order and the loss rate constant is independent of particle size. Therefore, the rate constant, $k$, of aerosol mass loss to the wall is given by a linear fitting of aerosol volume concentration against time:

$\ln V(t)=-k t+C$

where $V(t)$ is the aerosol volume concentration measured at time $t$. Parameter $C$ is a constant. A plot of $\ln V(t)$ versus time, such as that shown in Fig. 1a, provides the aerosol mass loss rate constant $k\left(\min ^{-1}\right)$. The value of $k$ was estimated using the measurements after the oxidation reactivity had completely stopped in the $\mathrm{OH}$-dominated chemistry or the reactivity fraction contributed less than $10 \%$ of total reactivity in the $\mathrm{O}_{3}$-initiated chemistry. To establish this 

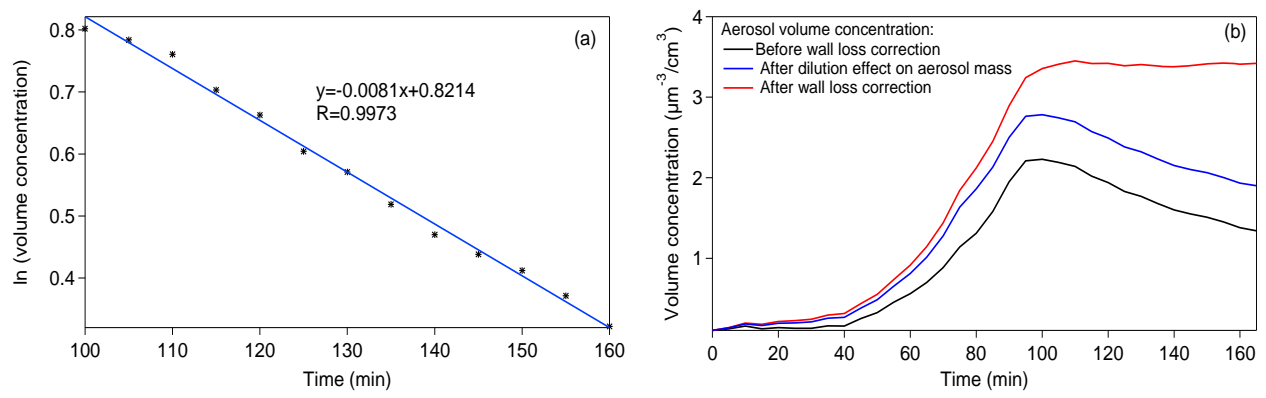

Fig. 1. (a) Logarithm of measured volume concentration as a function of time in smog chamber in experiment P1023. Aerosol wall loss rate was obtained from the fitting Eq. (3). (b) Aerosol volume concentration after taking account into aerosol depositions on the chamber wall and dilution effects. Black curve is the directly measured aerosol volume concentration as a function of time in smog chamber. Blue curve is for the aerosol volume concentration after taking into account dilution effects arising from the ozone addition at $40 \mathrm{~L} \mathrm{~min}^{-1}$ for 75 min. Red curve shows the corrected volume concentration by applying the wall loss factor derived in (a).

we used model estimates of $\mathrm{OH}$ concentrations that are described in greater detail in Hao et al. (2009). The experimental data fit to Eq. (3) was excellent $\left(R^{2}>0.95\right)$, which gives us confidence that the model assumptions of diameterindependent volume loss and negligible gas-particle partitioning during the analysis period were valid. The parameter $k$ varied from 0.0026 to $0.0084 \mathrm{~min}^{-1}$ in these experiments $\left(0.16 \mathrm{~h}^{-1}-0.5 \mathrm{~h}^{-1}\right)$. It is presumed to reflect air circulation in the chamber and variations of chamber volume due to the experimental operations as a sequence of the introduction of clear air to the chamber and continuously sampling by the instruments FMPS, PTR-MS and GC-MS, etc.

The produced SOA volume concentration is therefore given by

$V^{\prime}(t)=V(t)+k \int_{0}^{t} V(t) d t$

where $V^{\prime}(t)$ is the aerosol volume concentration after wall loss correction and $V(t)$ is the aerosol concentration before correction.

\subsection{Dilution effects on aerosol mass concentrations}

In this study, addition of ozone into the chamber was operated at a fixed flow rate $40 \mathrm{~L} \mathrm{~min}^{-1}$ for a fixed time as shown in Table 1. Changes of aerosol mass concentration caused by the dilution from the ozone addition must also be taken into account. Effect of dilution on the aerosol mass can be estimated by the following equation

$M_{\mathrm{o}, t}^{\prime}=M_{\mathrm{o}, t}+\int_{0}^{t}\left(F \cdot M_{\mathrm{o}, t}\right) d t$

where $M_{\mathrm{o}, t}^{\prime}$ is aerosol mass concentration after taking into account the dilution effect at time $t, M_{\mathrm{o}, t}$ is aerosol mass loading before the dilution effect correction at time $t . F$ is the dilution effect factor on the aerosol mass concentration, which is estimated from model simulation according to the inlet flow $40 \mathrm{~L} \mathrm{~min}^{-1}$ and out flow $15 \mathrm{~L} \mathrm{~min}^{-1}$ and simulated chamber volume during the operation of smog chamber. It is approximated to be $4.0 \times 10^{-3} \mathrm{~min}^{-1}$ during ozone addition into the chamber in this study. As an example, the corrected aerosol mass loading after dilution effect is shown in Fig. 1 b.

\subsection{Modeling}

Kinetic degradation mechanisms of $\alpha$-pinene and real plant emissions by the $\mathrm{O}_{3}$ and $\mathrm{OH}$ in the chamber were simulated by a kinetic chemical box model. Detailed model description and simulation parameters are provided in Hao et al. (2009). Briefly, the evolution of $\mathrm{O}_{3}$ concentration in the chamber can be expressed as

$$
\begin{aligned}
\frac{d\left[\mathrm{O}_{3}\right]}{d t} & =\frac{d\left[\mathrm{O}_{3}\right]_{\text {inlet }}}{d t}-\gamma k_{\mathrm{O}_{3}}^{\mathrm{TME}}[\mathrm{TME}]\left[\mathrm{O}_{3}\right]-\gamma_{\mathrm{IP}}^{\prime} k_{\mathrm{O}_{3}}^{\mathrm{IP}}[\mathrm{IP}]\left[\mathrm{O}_{3}\right] \\
& -\sum_{i} \gamma_{i}^{\prime} k_{\mathrm{O}_{3}}^{\mathrm{MT}_{i}}[\mathrm{MT}]_{i}\left[\mathrm{O}_{3}\right]
\end{aligned}
$$

where MT and IP represents monoterpenes and isoprene, respectively. $\gamma, \gamma_{\mathrm{IP}}^{\prime}$ and $\gamma_{i}^{\prime}$ are the correction factors to take into account the secondary loss of ozone with products and $k$ represents rate constants.

The time-dependent $\mathrm{OH}$ concentration can be approximated by

$$
\begin{aligned}
\frac{d[\mathrm{OH}]}{d t} & =\omega_{i} k_{\mathrm{O}_{3}}^{\mathrm{TME}}[\mathrm{TME}]\left[\mathrm{O}_{3}\right]+\omega_{\mathrm{IP}}^{\prime} k_{\mathrm{O}_{3}}^{\mathrm{IP}}[\mathrm{IP}]\left[\mathrm{O}_{3}\right] \\
& +\sum_{i} \omega_{i}^{\prime} k_{\mathrm{O}_{3}}^{\mathrm{MT}_{i}}[\mathrm{MT}]_{i}\left[\mathrm{O}_{3}\right]-\gamma^{\prime \prime} k_{\mathrm{OH}}^{\mathrm{TME}}[\mathrm{TME}][\mathrm{OH}] \\
& -\gamma_{\mathrm{IP}}^{\prime \prime \prime} k_{\mathrm{OH}}^{\mathrm{IP}}[\mathrm{IP}][\mathrm{OH}]-\sum_{i} \gamma_{i}^{\prime \prime \prime} k_{\mathrm{OH}}^{\mathrm{MT}_{i}}[\mathrm{MT}]_{i}[\mathrm{OH}],
\end{aligned}
$$

where $\omega_{i}$ and $\omega_{i}^{\prime}$ denote the yields of hydroxyl radicals from the $\mathrm{O}_{3}$ reactions with VOCs, $\gamma^{\prime \prime}, \gamma_{\mathrm{IP}}^{\prime \prime \prime}$ and $\gamma_{i}^{\prime \prime \prime}$ are the correction factors to take into account the secondary loss of $\mathrm{OH}$ by reaction with products. 

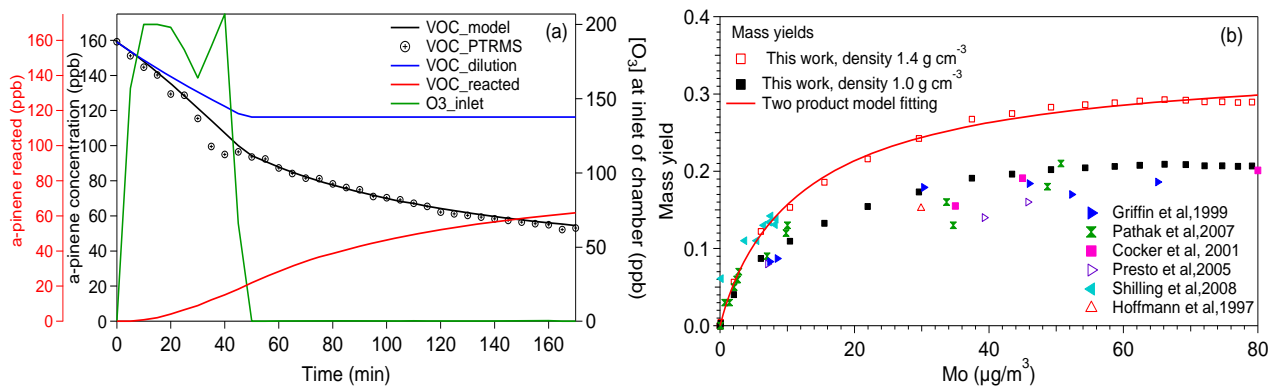

Fig. 2. Exp. R1024: (a) the time evolution of $\alpha$-pinene concentration. Blue curve: change of $\alpha$-pinene concentration due to the dilution of ozone addition into the chamber; black curve: $\alpha$-pinene decay profile from the chemical kinetic model; black markers: $\alpha$-pinene decay profile from PTR-MS measurement; red curve: changes in $\alpha$-pinene concentration upon reaction (excluding the dilution effect); green line: ozone concentration at inlet of chamber. (b) SOA mass yields as a function of aerosol concentration. The red empty rectangles are shown from the experimental data by using the determined aerosol density $1.4 \mathrm{~g} \mathrm{~cm}^{-3}$ and the red dotted line were fitted by a two-product partitioning model with values $0.3326,0.0760,0.0129$ and 2.6826 for $\alpha_{1}, K_{\mathrm{om}, 1}, \alpha_{2}$, and $K_{\mathrm{om}, 2}$, respectively. The black compact rectangles shown are adjusted to $\rho=1.0 \mathrm{~g} \mathrm{~cm}^{-3}$ to facilitate the comparison with other studies.

The degradation of VOCs is modeled as follows:

$\frac{d[\mathrm{VOC}]_{i}}{d t}=-k_{\mathrm{O}_{3}}^{\mathrm{VOC}_{i}}[\mathrm{VOC}]_{i}\left[\mathrm{O}_{3}\right]-k_{\mathrm{OH}}^{\mathrm{VOC}_{i}}[\mathrm{VOC}]_{i}[\mathrm{OH}]$

As a result we can calculate $\mathrm{O}_{3}$ and $\mathrm{OH}$ oxidation rates with VOCs as follows:

$r_{\mathrm{O}_{3}}=\sum_{i} k_{\mathrm{O}_{3}}^{\mathrm{MT}_{i}}[\mathrm{MT}]_{i}\left[\mathrm{O}_{3}\right]+k_{\mathrm{O}_{3}}^{\mathrm{IP}}[\mathrm{IP}]\left[\mathrm{O}_{3}\right]$

$r_{\mathrm{OH}}=\sum_{i} k_{\mathrm{OH}}^{\mathrm{MT}_{i}}[\mathrm{MT}]_{i}[\mathrm{OH}]+k_{\mathrm{OH}}^{\mathrm{IP}}[\mathrm{IP}][\mathrm{OH}]$

According to above simulations, $\mathrm{OH}$ and $\mathrm{O}_{3}$ initiated reactivity fractions (Fra.) can be determined:

Fra. $(\mathrm{OH})=\frac{\int_{0}^{t} r_{i, \mathrm{OH}(t)} d t}{\int_{0}^{t} r_{i, \mathrm{OH}(t)} d t+\int_{0}^{t} r_{i, \mathrm{O}_{3}(t)} d t}$

$\operatorname{Fra} \cdot\left(\mathrm{O}_{3}\right)=\frac{\int_{0}^{t} r_{i, \mathrm{O}_{3}(t)} d t}{\int_{0}^{t} r_{i, \mathrm{OH}(t)} d t+\int_{0}^{t} r_{i, \mathrm{O}_{3}(t)} d t}$

where $r_{i, \mathrm{OH}(t)}$ and $r_{i, \mathrm{O}_{3}(t)}$ are the reaction rates of $\mathrm{VOC}_{i}$ with $\mathrm{OH}$ and $\mathrm{O}_{3}$ at time $t(\mathrm{~min})$, respectively.

\section{Results and discussions}

\subsection{SOA mass yield}

The SOA mass yield $(Y)$ is determined by calculating the ratio of aerosol mass concentration $M_{\mathrm{o}}\left(\mathrm{in} \mu \mathrm{g} \mathrm{m}^{-3}\right)$ to the amount of total precursor VOCs reacted ( $\triangle \mathrm{HC}$, in $\mu \mathrm{g} \mathrm{m}^{-3}$ ) at the end of each experiment

$Y=M_{\mathrm{o}} / \Delta \mathrm{HC}$
The yields can also be further described by a semi-empirical model based on absorptive gas-particle partitioning of semivolatile products (Odum et al., 1996; Pankow, 1994a, b). Usually one or two products can generally reproduce the chamber data:

$Y=M_{\mathrm{o}}\left(\frac{\alpha_{1} K_{\mathrm{om}, 1}}{1+K_{\mathrm{om}, 1} M_{\mathrm{o}}}+\frac{\alpha_{2} K_{\mathrm{om}, 2}}{1+K_{\mathrm{om}, 2} M_{\mathrm{o}}}\right)$

where $\alpha_{i}$ is the mass-based gas-phase stoichiometric fraction for semi-volatile species $i$ and $K_{\mathrm{om}, i}$ is the gas-phase partitioning coefficient for species $i$.

\subsection{SOA yields from $\alpha$-pinene}

Aerosol yields can be determined from progressive changes in VOC concentration and in aerosol mass concentration during a single experiment for the compound with one $\mathrm{C}=\mathrm{C}$ bond (Ng et al., 2006). Figure 2 shows SOA mass yields as a function of absorptive organic mass concentration from $\alpha$ pinene oxidation (R1024, ref. Table 1). The effect of dilution on $\alpha$-pinene concentration is shown in Fig. 2a (where ozone addition into the chamber occurred at flow of $40 \mathrm{~L} \mathrm{~min}^{-1}$ for $50 \mathrm{~min})$. This dilution effect has been taken into account in the mass yield calculations. Comparisons of our SOA mass yields are made to literature reports for dark ozonolysis of $\alpha$-pinene (Fig. 2b). Temperature (298 K) in this study is $3 \mathrm{~K}$ higher than Presto et al. (2005) and Presto and Donahue (2006) and $5 \mathrm{~K}$ lower than Griffin et al. (1999) and Cocker et al. (2001). No adjustments for temperature effects on the mass yields were made, which might cause over- or under-estimation on the mass yields (Pathak et al., 2007). Findings presented in this study were reproduced by a two-product absorptive partitioning model with parameters of values $0.3326,0.0760,0.0129$ and 2.6826 for $\alpha_{1}, K_{\mathrm{om}, 1}$, $\alpha_{2}$, and $K_{\mathrm{om}, 2}$, respectively. These results are compare well to literature values, though lower than those at low organic 
Table 2. SOA mass yields from $\mathrm{OH}$ and $\mathrm{O}_{3}$ initiated oxidation of real emissions of two boreal forest trees. Reactivity fraction (Rea. Fra.) was calculated using Eqs. (11-12).

\begin{tabular}{|c|c|c|c|c|c|c|c|}
\hline \multirow[t]{2}{*}{ Systems } & \multirow[t]{2}{*}{ Exp. No. } & \multirow{2}{*}{$\begin{array}{l}\text { VOCs } \\
(\mathrm{ppb})\end{array}$} & \multirow{2}{*}{$\begin{array}{l}\Delta \mathrm{HC} \\
(\mathrm{ppb})\end{array}$} & \multirow{2}{*}{$\begin{array}{r}\mathrm{M}_{o} \\
\left(\mu \mathrm{g} \mathrm{m}^{-3}\right)\end{array}$} & \multicolumn{2}{|c|}{ Rea. Fra. $(\%)$} & \multirow{2}{*}{$\begin{array}{r}\text { Yield } \\
(\%)\end{array}$} \\
\hline & & & & & $\mathrm{OH}$ & $\mathrm{O}_{3}$ & \\
\hline \multirow{4}{*}{ OH-dominated } & S1019 & 217.4 & 43.4 & 32.8 & 91.5 & 8.5 & 13.6 \\
\hline & P1025 & 113.8 & 26.2 & 21.7 & 89.5 & 10.5 & 15.0 \\
\hline & P1023 & 28.8 & 7.45 & 4.62 & 89.2 & 10.8 & 11.2 \\
\hline & P1012 & 74.1 & 26.5 & 26.0 & 83.7 & 16.3 & 17.7 \\
\hline \multirow{4}{*}{$\mathrm{O}_{3}$-initiated } & R1024 & 159.2 & 49.2 & 79.1 & 42.1 & 57.9 & 28.9 \\
\hline & P1022 & 23.2 & 6.69 & 3.12 & 36.7 & 63.3 & 8.4 \\
\hline & S1017 & 28.2 & 6.67 & 0.69 & 36.1 & 63.9 & 1.9 \\
\hline & S1015 & 94.7 & 13.9 & 9.62 & 33.8 & 66.2 & 12.4 \\
\hline Ozonolysis dominated & P1026 & 100.3 & 22.6 & 12.6 & 0.9 & 99.1 & 10.0 \\
\hline
\end{tabular}

mass loading from Shilling et al. (2008), which is attributed to changes of product species from the unique mix of both parent hydrocarbon species and oxidants used in these two studies (possibly peroxy radicals or hydroperoxide species; Shilling et al., 2008).

\subsection{Chemical composition of living plant emissions}

BVOC precursors in this study came from emissions of 1yr-old Scots pine and Norway spruce seedlings. Cultivation and pretreatments of these seedlings have been described in Hao et al. (2009). In order to enhance total BVOCs emissions and simulate herbivore attack on tree bark, $3 \mathrm{~cm}$ long and $2 \mathrm{~mm}$ deep cuts were made on the base of main stem by a knife. Abiotic or biotic damage on the plant can change the BVOC emission profiles (e.g. Blande et al., 2009). However the BVOC emission spectrum in this study (major compounds in the emission profile) is comparable to ambient observations. Molar chemical composition of emissions from these two types of forest trees are shown in Fig. 3. Emitted monoterpenes from Scots pine mainly included $\alpha$-pinene and $\Delta^{3}$-carene, matching the field observations in the boreal Scots pine dominated forest (e.g. Räisänen et al., 2009; Manninen et al., 1998). No fractional contribution of $\Delta^{3}$-carene in P1025 and P1026 were observed which depends on the $\Delta^{3}$-carene genotype Scots pine (Manninen et al., 1998). The most abundant contributions from Norway spruce emission are $\alpha$-pinene and $\beta$-pinene, making up $64.8 \%, 60.2 \%$ and $57.3 \%$ of total emitted monoterpenes for S1019, S1017 and S1015, respectively. These results are comparable to $70 \%$ of flux contribution of $\alpha$-pinene and $\beta$-pinene to total emissions during measurements made in a spruce dominated forest (Christensen et al., 2000). Other major contributions to emissions from these two types of trees came from myrcene, $\beta$-phellandrene and limonene. In all experiments, sesquiterpenes in the emitted compounds were lower than $0.05 \mathrm{ppb}$ as

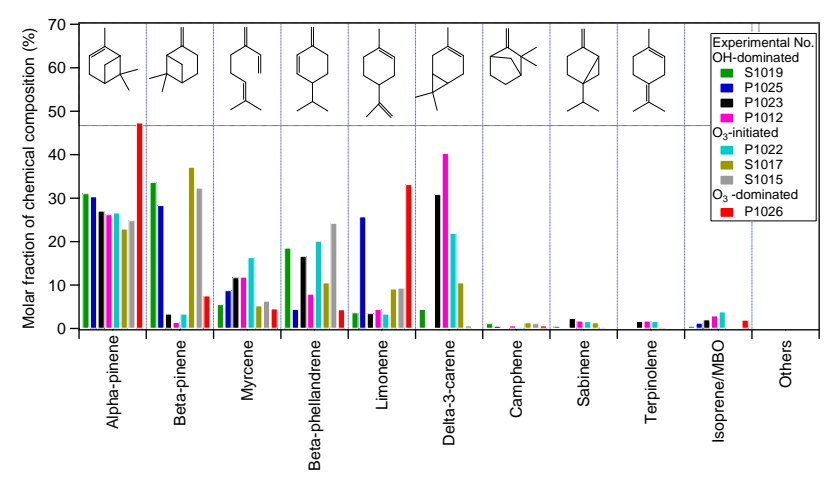

Fig. 3. Percentage molar contributions of detected individual BVOC from plant emissions in different experiments and corresponding BVOC molecular structures.

determined with PTR-MS. The molecular structures of these compounds can have an impact on the final formed SOA mass yields and will be discussed in the next section.

\subsection{SOA yields from pine and spruce emissions}

Once ozone is introduced into the chamber, the parent hydrocarbon precursors from tree seedlings decay and new particle formation begins within 20-40 min. Observations from these experiments are analyzed using the same processing procedures as the $\alpha$-pinene experiment and are tabulated in Table 2. The SOA mass yields from these real plant emissions varied from $1.9 \%$ at $M_{\mathrm{o}}=0.69 \mu \mathrm{g} \mathrm{m}^{-3}$ to $17.7 \%$ at $M_{\mathrm{o}}=26.0 \mu \mathrm{g} \mathrm{m}^{-3}$. The mass yield curve ( $Y$ vs. $M_{\mathrm{o}}$ ) can be reproduced by a two-product gas-particle partitioning model with parameters of $0.1462,0.3850,0.0531$ and 0.0160 for $\alpha_{1}$, $K_{\mathrm{om}, 1}, \alpha_{2}$, and $K_{\mathrm{om}, 2}$, respectively at the $95.4 \%$ confidence level though datasets scattered in Fig. 4. Previous studies have shown the presence of $\mathrm{a}=\mathrm{CH}_{2}$ bond, the position of 
$\mathrm{C}=\mathrm{C}$ bonds in the molecular ring structure and the numbers of $\mathrm{C}=\mathrm{C}$ bonds in these types of compounds can affect the volatility of condensable products and the final yields (Kroll et al., 2008; Ng et al., 2006, 2007; Bonn and Moortgat, 2002; Griffin et al., 1999). The interactive effects of these complex mixtures of different compounds and chemical mechanisms during the reactions with $\mathrm{OH}$ and $\mathrm{O}_{3}$ are likely reasons for this scatter.

In this study, SOA yields from real plant emissions are generally lower than that from $\alpha$-pinene, as shown in Fig. 4. One possible reason for this is that lower volatility condensable products were formed in the $\alpha$-pinene experiment compared to the real plant cases; this will be discussed in next section. Field observations from a typical boreal monoterpene-emission dominated forest site in Hyytiälä, Finland, show the organic mass loading ranges from around $0.5 \mu \mathrm{g} \mathrm{m}^{-3}$ to about $6 \mu \mathrm{g} \mathrm{m}^{-3}$ (Raatikainen et al., 2010; Tunved et al., 2006a). These particulate organics are in a form of oxygenated organic aerosol (OOA) (Allan et al, 2006; Raatikainen et al., 2010) and can be approximated to be organic absorption materials $\left(\sum M_{\mathrm{o}}\right)$. Thus corresponding SOA mass yields from these observations are estimated to range from $3 \%$ to $11 \%$, in good agreement with the suggested values 5-10\% derived for the boreal forest (Tunved et al., 2006a, b). Ambient biogenic SOA mass loadings (assumed to be organic absorption materials) on a global scale vary from 0.1 to $20 \mathrm{\mu g} \mathrm{m}^{-3}$ (Shilling et al., 2009), spanning the measured mass yields of $0.5 \%$ to $14 \%$ based on the interpolation in our study (Fig. 4). Assuming an average mass concentrations for global biogenic SOA of $M_{\mathrm{o}}=5 \pm 3 \mu \mathrm{g} \mathrm{m}^{-3}$ (Slowik et al., 2010; Raatikainen et al., 2010; Tunved et al., 2006a), this corresponds to an average mass yield $10 \pm 2 \%$ on a global scale.

Few mass yields have been reported from chamber studies of real plant BVOC oxidation. Mentel et al. (2009) reported incremental mass yields of SOA from $\mathrm{OH} / \mathrm{O}_{3}$ initiated pine/spruce emissions. They used a flow reaction chamber with VOC residence time of about $65 \mathrm{~min}$ and ozone level $\leq 80 \mathrm{ppb}$. For better comparison of these results with our observations, we consider mass yields from only the monoterpene precursors, observed to be $5.2 \pm 0.5 \%, 5.3 \pm 0.6 \%$ and $3.5 \pm 0.6 \%$ for $\alpha$-pinene, pine and spruce SOAs, respectively. Based on the maximum organic absorption concentrations in Mentel et al. (2009) for $\alpha$-pinene (around $4.1 \mu \mathrm{g} \mathrm{m}^{-3}$ ), pine $\left(2.8 \mu \mathrm{g} \mathrm{m}^{-3}\right)$ and spruce $\left(1.1 \mu \mathrm{g} \mathrm{m}^{-3}\right)$ SOA (see Fig. 10 , Mentel et al., 2009), the mass yields in this study were interpolated to be $9 \%, 8 \%$ and $4 \%$ for $\alpha$-pinene, pine and spruce SOA, respectively. Their reported values are slightly lower than ours. This difference in mass yields may be due to differences in experimental conditions, e.g., residence times that are greater and aerosols slightly more aged in our batchmode chamber experiments in contrast to the flow chamber used in Mentel et al.

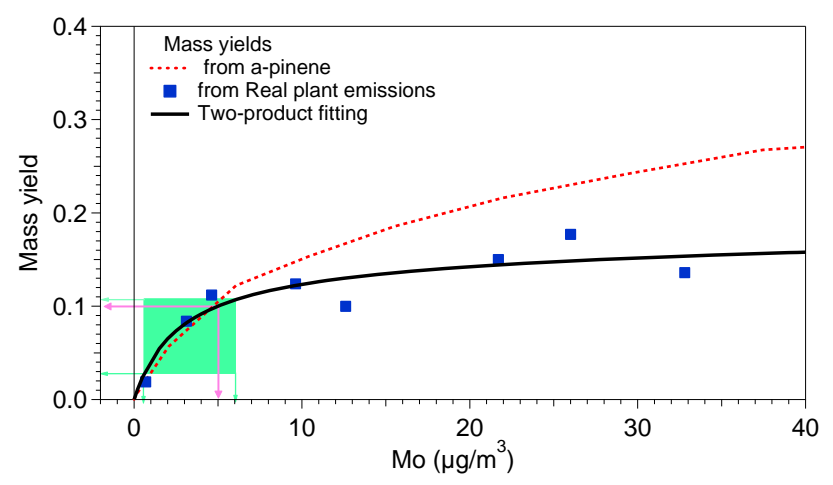

Fig. 4. The SOA mass yield curve from real plant emissions compared to $\alpha$-pinene experiment. The blue rectangles are for SOA yields from each real plant emissions. The red dotted line is from the $\alpha$-pinene SOA mass yields. Black solid curve is fitted to the real plant SOA yields by a two-product absorptive partitioning model with parameters of $0.1462,0.3850,0.0531$ and 0.0160 for $\alpha_{1}$, $K_{\mathrm{om}, 1}, \alpha_{2}$, and $K_{\mathrm{om}, 2}$, respectively. The dark green bar shows the organic mass loadings in the aerosol phase observed in a boreal forest area, Hyytiälä (Raatikainen et al., 2010; Tunved et al., 2006a). The pink arrow points to an estimation of average global biogenic SOA mass concentration $\left(5 \pm 3 \mu \mathrm{g} \mathrm{m}^{-3}\right)$, corresponding to a SOA mass yield of $10 \pm 2 \%$.

\section{5 $\mathrm{OH}$ - and $\mathrm{O}_{3}$-initiated chemistry}

$\mathrm{OH}$ initiates oxidation of VOCs either by abstraction of a hydrogen atom or addition to a $\mathrm{C}=\mathrm{C}$ bond. The subsequent reactions are dominated by the organic peroxy radical $\left(\mathrm{RO}_{2}\right)$ and alkoxy radical ( $\left.\mathrm{RO}\right)$ chemistry. Oxidation of VOCs by ozone proceeds by the formation of ozonide and decomposition of this compound to generate various products via Criegee intermediate (CI). The fundamentally different mechanisms of $\mathrm{O}_{3}$ versus $\mathrm{OH}$ initiated oxidation play a crucial role in determining the product volatility and are thus controlling factors in SOA mass yield. Further oxidation of semi-volatile products in the gas and particle phase (Kroll et al., 2007; Chan et al., 2007) and secondary generation products ( $\mathrm{Ng}$ et al., 2006) caused by $\mathrm{OH}$ and $\mathrm{O}_{3}$ could also alter final SOA production. Moreover, organic products in the condensed phase may also undergo chemical reactions, affecting their physicochemical properties (Joutsensaari et al., 2004) and volatility (Paulsen et al., 2006; Dommen et al., 2006; Baltensperger et al., 2005; Kalberer et al., 2004). The volatility of $30 \mathrm{~nm}$ and $50 \mathrm{~nm}$ diameter SOA at temperature of $150^{\circ} \mathrm{C}$, formed in the $\mathrm{OH}$-dominated and $\mathrm{O}_{3}$-initiated chemical systems, is displayed in Fig. 5. The volatility growth factors in the $\mathrm{OH}$-dominated experiments are consistently $20-50 \%$ smaller than those in the $\mathrm{O}_{3}$-initiated systems with exception of P1012, indicating a higher volatility of condensable products for $\mathrm{OH}$-dominated chemistry in these experiments. The difference in volatility of these two types systems might be due to the $\mathrm{RO}_{2}$ and 

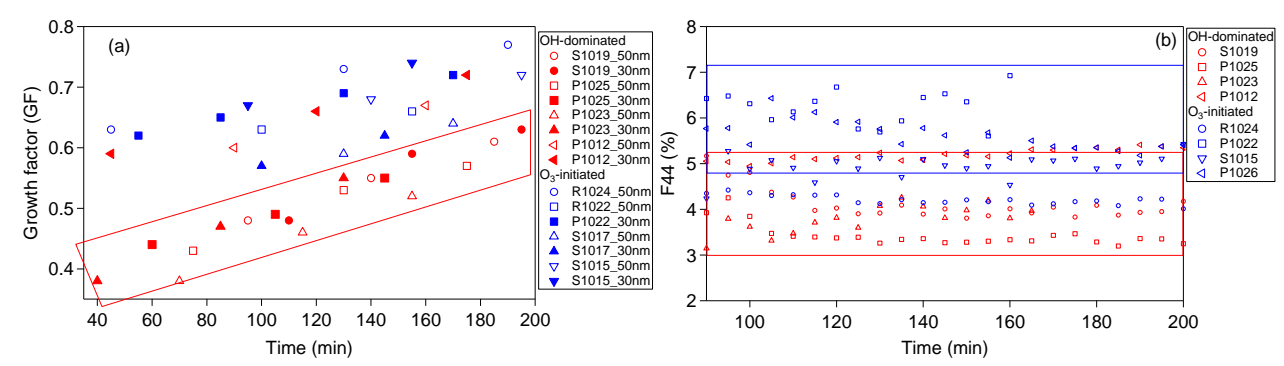

Fig. 5. (a) Volatility growth factor determined by V-TDMA for $30 \mathrm{~nm}$ and $50 \mathrm{~nm} \mathrm{SOA}$ at temperature of $150^{\circ} \mathrm{C}$. (b) The fraction of $\mathrm{m} / \mathrm{z}$ 44 to total organic mass (F44), a proxy for oxidation state, as measured by the Q-AMS. Red markers are presented for the OH-dominated chemistry and blue markers are for $\mathrm{O}_{3}$-initiated systems. No V-TDMA measurement was made in P1026. F44 from S1017 is noisy due to the low aerosol mass (Table 2) and are not shown in (b).

RO chemistry, where the dissociation reaction of condensable products might dominate in the $\mathrm{OH}$-dominated chemistry leading to the higher volatility products. The volatility of these particles can be further investigated with Q-AMS measurements of aerosol composition. It has been reported that aerosol volatility is positively correlated to the oxidation state of the particulate matter ( $\mathrm{Ng}$ et al., 2010; Jimenez et al., 2009). The fraction of fragment mass 44 to total measured organics (f44) in our OH-dominated chemistry, a marker of aerosol oxidation degree (e.g. $\mathrm{Ng}$ et al., 2010; Jimenez et al., 2009), contributes to around 3-4\% of total organic mass loading. This is systematically lower than the 5-6\% observed in the $\mathrm{O}_{3}$-initiated systems except for P1012, indicating less oxidized, and thus higher volatility, $\mathrm{SOA}$ in our $\mathrm{OH}-$ dominated systems. Note that though the diameter cutoff of the Q-AMS is around $30 \mathrm{~nm}$ (Zhang et al., 2004), the fraction of mass 44 presented here is from the entire bulk aerosol but still should be the representative of $50 \mathrm{~nm}$ particle size, since an internal mixture can be assumed for the SOA. The low volatility in P1012 appears related to the higher fractional contribution of ozonolysis reactivity than other three $\mathrm{OH}$-dominated systems (see Table 2).

Lower volatility of condensable products in the $\mathrm{O}_{3}$ initiated systems appears at first counterintuitive to previous results (Hao et al., 2009) reporting that $\mathrm{OH}$ oxidation products are more effective in causing nucleation; whereas the ozonolysis products are more effective in driving particle growth. In principle, nucleation rate depends on the ratio of the density of the nucleating vapor to its saturation vapor density (i.e. saturation ratio), whereas the particle growth rate depends on the difference of the vapor density and saturation density. Thus, a compound with low volatility can have a supersaturation high enough for nucleation but still a relatively low vapor density so that the growth rate remains slow. On the other hand, a compound which has a higher volatility and becomes supersaturated may cause a rapid growth although the saturation ratio is not high enough for nucleation.
However, a simple example calculation shows that the Hao et al. (2009) results are not necessarily in contradiction with the volatilities detected with the V-TDMA. Consider experiments E1b ( $\mathrm{OH}$ chemistry) and E3 $\left(\mathrm{O}_{3}\right.$ chemistry) in Hao et al. (2009). From the growth rates it can be roughly estimated that the concentration differences between vapor densities and saturation densities are $0.03 \mathrm{ppb}$ in experiment $\mathrm{E} 1 \mathrm{~b}$ and $0.11 \mathrm{ppb}$ in E3. Assuming that the saturation vapor density of the $\mathrm{OH}$ products is two times that of the ozonolysis products and that the saturation ratio in experiment E1b was 5 , it can be calculated that the saturation ratio in E3 was 30 . This is completely possible, especially as the temperature in the experiments was similar and thus the reduced temperature (temperature divided by critical temperature) was lower in E3. It is well known that the onset saturation ratio for nucleation usually increases exponentially with decreasing reduced temperature (see e.g. McGraw, 1981).

Note, however, that we cannot exclude possibilities explaining the nucleation in E1b such as a minor reaction channel forming very low volatility species that dominates nucleation, or formation of sulfuric acid in $\mathrm{OH}$ reaction with contaminant background $\mathrm{SO}_{2}$. In any case, more thorough examination of the different pathways for nucleation requires future experiments.

For the $\mathrm{O}_{3}$-initiated systems, volatility growth factors in R1024 show the highest value as displayed in Fig. 5a, suggesting that volatility of condensable products is not only oxidant-dependent, but also depends on the molecular structure of the parent hydrocarbons. The compound $\alpha$-pinene has one double bond internal to the ring structure, which is more likely to form condensable products when compared to compounds with external double bonds during ozonolysis reaction (Griffin et al., 1999). Whereas the high fractional contribution of compounds with external double bonds to emissions such as $\beta$-pinene and $\beta$-phellandrene can be in part responsible for the higher volatility of condensable products in the other three $\mathrm{O}_{3}$-initiated experiments. In contrast, for $\mathrm{OH}$-dominated chemistry, compounds with $=\mathrm{CH}_{2}$ bond and internal double bond to ring structure, such as $\beta$-pinene 
and $\Delta^{3}$-carene, lose fewer carbon atoms under oxidant attack, which generally leads to lower volatility condensable products (Griffin et al., 1999).

In this study, volatility growth factors generally increased as a function of reaction time in this study as shown in Fig. 5a; the trend is especially noticeable for the $\mathrm{OH}$ dominated experiments. As a closer look at the mechanism, Fig. 6 shows the time evolution of volatility of $50 \mathrm{~nm}$ sized particle at $150^{\circ} \mathrm{C}$ in $\mathrm{P} 1023$ as one representative of $\mathrm{OH}$ dominated chemistry. It is interesting to observe that aerosol volatility is still decreasing (that is, volatility growth factor trends closer to 1 ) during the time period marked by pink bar. During this period, both $\mathrm{O}_{3}$ and $\mathrm{OH}$ were completely consumed and no new particle formation was observed (geometric mean diameter remains constant and aerosol volume concentration goes down due to the aerosol deposition to the chamber wall). This is a strong indication that an aging process is occurring in the particle phase, resulting in a lower volatility of aerosols. Note that Virtanen et al. (2010) found that particles formed in the plant chamber are in a glassy state, and we cannot rule out the possibility that the particles are initially in a liquid state, but become more glasslike and less volatile with the aging. Formation of lowvolatility components of SOA formed from photooxidation of $\alpha$-pinene (Paulsen et al., 2006; Baltensperger et al., 2005), aromatic compounds (Kalberer et al., 2004; Baltensperger et al., 2005), and isoprene (Dommen et al., 2006) have also been observed even after the completion of gas-phase chemistry. Those components are usually as a result of formation of high molecular weight compounds from oligomerization or polymerization processes. This mechanism should also be applicable to our systems. The decrease of aerosol volatility will favor final SOA condensation but the magnitude of this effect on final SOA yield remains uncertain and needs to be addressed in future studies.

\section{Summary and conclusions}

We have reported laboratory studies of newly formed aerosols resulting from the oxidation of direct emissions of two dominant tree species from boreal forest area, Scots pine (Pinus sylvestris L.) and Norway spruce (Picea abies). New particle formation events from $\mathrm{OH}$-dominated and $\mathrm{O}_{3}$ initiated chemistry were studied by adding TME and 2butanol to adjust the $\mathrm{OH}$ and $\mathrm{O}_{3}$ levels. The evolution of gaseous species was measured by PTR-MS and GC-MS instrumentations. Aerosol mass loading was calculated from the FMPS measurements by applying the determined aerosol density after taking into account the aerosol deposition on the chamber wall and dilution effect on the aerosol volume concentration.

Formation of SOA from $\alpha$-pinene oxidation can be reproduced with a two-product gas-particle partitioning absorption model. Determined mass yields in this study are in

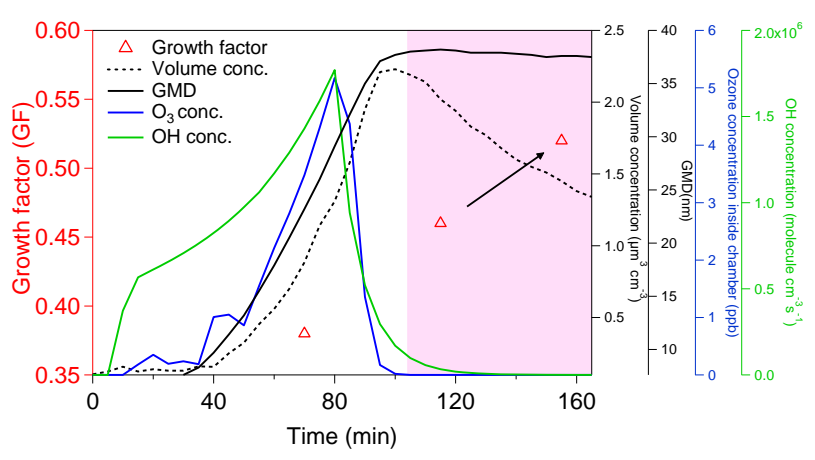

Fig. 6. Evolution of volatility of $50 \mathrm{~nm}$ SOA determined at temperature $150^{\circ} \mathrm{C}$ formed in $\mathrm{P} 1023$, as an example of the $\mathrm{OH}$-dominated chemistry in this study. Blue curve shows the measured ozone concentration inside the chamber; solid black curve is for Geometric Mean Diameter (GMD) from FMPS measurement; green curve is the simulated $\mathrm{OH}$ concentration inside the chamber from the model prediction; Dashed black curve is for the measured aerosol volume concentration inside the chamber. No oxidants were observed in the pink bar area.

a good agreement with a number of previous studies. For the SOA formation from real plant emissions, aerosol mass yields varied from $1.9 \%$ at $M_{\mathrm{o}} 0.69 \mu \mathrm{g} \mathrm{m}^{-3}$ to $17.7 \%$ at $M_{\mathrm{o}} 26.0 \mu \mathrm{g} \mathrm{m}^{-3}$. Volatility of condensable products from $\mathrm{OH}$-dominated experiments is consistently higher than those from $\mathrm{O}_{3}$-initiated chemistry during aerosol growth stage whereas the condensable products in the $\alpha$-pinene experiments show the lowest volatility as a result of effects of molecular structure of precursor compound on the product volatility. Products in the particle phase from $\mathrm{OH}$-dominated chemistry undergo an aging process that continues after gas-phase oxidants have been consumed, further decreasing volatility, which can affect final SOA formation. SOA production from real plant emissions depends on both chemical composition of plant emissions and oxidant species, but still can be reproduced with a two-product gas-phase partitioning model with parameters of $0.1462,0.3850,0.0531$ and 0.0160 for $\alpha 1, K_{\mathrm{om}, 1}, \alpha 2$, and $K_{\mathrm{om}, 2}$, respectively. As a potential atmospheric application of this study, SOA mass yields (3$11 \%$ ) obtained from these experiments are in the range reported for Hyytiälä, Finland, which is a typical European Boreal monoterpene-emission dominated forest region. On a global scale, the SOA mass yield of $10 \pm 2 \%$, based on this study, can be recommended.

The studies carried out here are designed to closely match atmospheric conditions, so that the results are applicable to real atmospheric aerosol modeling. More studies are planned to continue to investigate the roles that $\mathrm{OH}$ and $\mathrm{O}_{3}$ play aerosol formation from real plant emissions. 
Acknowledgements. The authors thank H. Korhonen for the helpful discussions on this work. The financial support by the Academy of Finland Centre of Excellence program (project no. 1118615), Academy of Finland (decision no. 110763, 131019, 218115, 111543, 123466), EU 6th framework EUCAARI and the Saastamoinen Foundation and the Office of Science (BER), US Department of Energy, grant DE-FG-02-05ER63997 is gratefully acknowledged. The National Center for Atmospheric Research is sponsored by the US National Science Foundation.

Edited by: R. Krejci

\section{References}

Allan, J. D., Alfarra, M. R., Bower, K. N., Coe, H., Jayne, J. T., Worsnop, D. R., Aalto, P. P., Kulmala, M., Hyötyläinen, T., Cavalli, F., and Laaksonen, A.: Size and composition measurements of background aerosol and new particle growth in a Finnish forest during QUEST 2 using an Aerodyne Aerosol Mass Spectrometer, Atmos. Chem. Phys., 6, 315-327, doi:10.5194/acp-6-315-2006, 2006.

Baltensperger, U., Kalberer, M., Dommen, J., Paulsen, D., Alfarra, M.R., Coe, H., Fisseha, R., Gascho, A., Gysel, M., Nyeki, S., Sax, M., Steinbacher, M., Prevot, A. S. H., Sjögren, S., Weingartner, E., and Zenobi, R.: Secondary organic aerosol from anthropogenic and biogenic precursors, Faraday Discuss., 130, 265-278, 2005.

Bonn, B. and Moorgat, G. K.: New particle formation during $\alpha$ and $\beta$-pinene oxidation by $\mathrm{O}_{3}, \mathrm{OH}$ and $\mathrm{NO}_{3}$, and the influence of water vapour: particle size distribution studies, Atmos. Chem. Phys., 2, 183-196, doi:10.5194/acp-2-183-2002, 2002.

Bahreini, R., Keywood, M. D., Ng, N. L., Varutbangkul, V., Gao, S., Flagan, R. C., Seinfeld, J. H., Worsnop, D. R., and Jimenez, J. L.: Measurements of secondary organic aerosol from oxidation cycloalkenes, terpenes, and m-Xylene using an Aerodyne Aerosol Mass Spectrometer, Environ. Sci. Technol., 39, 56745688, 2005.

Blande, J. D., Turunen, K., and Holopainen, J. K.: Pine weevil feeding on Norway spruce bark has a stronger impact on needle VOC emissions than enhanced UV-B radiation, Environ. Pollut., 157, 174-180, 2009.

Canagaratna, M. R., Jayne, J. T., Jimenez, J. L., Allan, J. D., Alfarra, M. R., Zhang, Q., Onasch, T. B., Drewnick, F., Coe, H., Middlebrook, A., Delia, A., Williams, L. R., Trimborn, A. M., Northway, M. J., DeCarlo, P. F., Kolb, C. E., Davidovits, P., and Worsnop, D. R.: Chemical and Microphysical Characterization of Ambient Aerosols with the Aerodyne Aerosol Mass Spectrometer, Mass Spectrom. Rev., 26, 185-222, 2007.

Chan, A. W. H., Kroll, J. H., Ng, N. L., and Seinfeld, J. H.: Kinetic modeling of secondary organic aerosol formation: effects of particle- and gas-phase reactions of semivolatile products, Atmos. Chem. Phys., 7, 4135-4147, doi:10.5194/acp-7-4135-2007, 2007.

Cai, X. and Griffin, R. J.: Secondary aerosol formation from the oxidation of biogenic hydrocarbons by chlorine atoms, J. Geophys. Res., 111, D14206, doi:10.1029/2005JD006857, 2006.

Cocker, D. R., Clegg, S. L., Flagan, R. C., and Seinfeld, J. H.: The effect of water on gas-particle partitioning of secondary or- ganic aerosol. Part 1: a-pinene/ozone system, Atmos. Environ., 35, 6049-6072, 2001.

Christensen, C. S., Hummelshøj, P., Jensen, N. O., Larsen, B., Lohse, C., Pilegaard, K., and Skov, H.: Determination of the terpene flux from orange species and Norway spruce by relaxed eddy accumulation, Atmos. Environ., 34, 3057-3067, 2000.

DeCarlo, P. F., Slowik, J. G., Worsnop, D. R., Davidovits, P., and Jimenez, J. L.: Particle morphology and density characterization by combined mobility and aerodynamic diameter measurements. Part 1: Theory, Aerosol Sci. Technol., 38, 1185-1205, 2004.

de Gouw, J. and Warneke, C.: Measurements of volatile organic compounds in the earth's atmosphere using proton-transferreaction mass spectrometry, Mass Spectrom. Rev., 26, 223-257, 2007.

Docherty, K. S. and Ziemann, P. J.: Effects of stabilized Criegee Intermediate and $\mathrm{OH}$ radical scavengers on aerosol formation from reactions of $\beta$-Pinene with $\mathrm{O}_{3}$, Aerosol Sci. Technol., 37, 877891, 2003.

Dommen, J., Metzger, A., Duplissy, J., Kalberer, M., Alfarra, M. R., Gascho, A., Weingartner, E., Prevot, A. S. H., Verheggen, B., and Baltensperger, U.: Laboratory observation of oligomers in the aerosol from isoprene/NOx photooxidation, Geophys. Res. Lett., 33, L13805, doi:10.1029/2006GL026523, 2006.

Fry, J. L., Kiendler-Scharr, A., Rollins, A. W., Wooldridge, P. J., Brown, S. S., Fuchs, H., Dubé, W., Mensah, A., dal Maso, M., Tillmann, R., Dorn, H.-P., Brauers, T., and Cohen, R. C.: Organic nitrate and secondary organic aerosol yield from $\mathrm{NO}_{3}$ oxidation of -pinene evaluated using a gas-phase kinetics/aerosol partitioning model, Atmos. Chem. Phys., 9, 1431-1449, doi:10.5194/acp9-1431-2009, 2009.

Guenther, A., Hewitt, C. N., Erickson, D., Fall, R., Geron, C., Graedel, T., Harley, P., Klinger, L., Lerdau, M., Mckay, W. A., Pierce, T., Scholes, B., Steinbrecher, R., Tallamraju, R., Taylor, J., and Zimmerman, P.: A global-model of natural volatile organic-compound emissions, J. Geophys. Res., 100, 88738892, 1995.

Griffin, R. J., Cocker III, D. R., Flagan, R. C., and Seinfeld, J. H.: Organic aerosol formation from the oxidation of biogenic hydrocarbons, J. Geophys. Res., 104(D4), 3555-3567, doi:10.1029/1998JD100049, 1999.

Hallquist, M., Wenger, J. C., Baltensperger, U., Rudich, Y., Simpson, D., Claeys, M., Dommen, J., Donahue, N. M., George, C., Goldstein, A. H., Hamilton, J. F., Herrmann, H., Hoffmann, T., Inuma, Y., Jang, M., Jenkin, M. E., Jimenez, J. L., Kiendler-Scharr, A., Maenhaut, W., McFiggans, G., Mentel, Th. F., Monod, A., Prévôt, A. S. H., Seinfeld, J. H., Surratt, J. D., Szmigielski, R., and Wildt, J.: The formation, properties and impact of secondary organic aerosol: current and emerging issues, Atmos. Chem. Phys., 9, 5155-5236, doi:10.5194/acp-95155-2009, 2009.

Hao, L. Q., Yli-Pirilä, P., Tiitta, P., Romakkaniemi, S., Vaattovaara, P., Kajos, M. K., Rinne, J., Heijari, J., Kortelainen, A., Miettinen, P., Kroll, J. H., Holopainen, J. K., Smith, J. N., Joutsensaari, J., Kulmala, M., Worsnop, D. R., and Laaksonen, A.: New particle formation from the oxidation of direct emissions of pine seedlings, Atmos. Chem. Phys., 9, 8121-8137, doi:10.5194/acp9-8121-2009, 2009.

Hoffmann, T., Odum, J. R., Bowman, F., Collins, D., Klockow, D., Flagan, R., and Seinfeld, J. H.: Formation of organic aerosols 
from the oxidation of biogenic hydrocarbons, J. Atmos. Chem., 26, 189-222, 1997.

Jayne, J. T., Leard, D. C., Zhang, X. F., Davidovits, P., Smith, K. A., Kolb, C. E., and Worsnop, D. R.: Development of an Aerosol Mass Spectrometer for size and composition analysis of submicron particles, Aerosol Sci. Technol., 33, 49-70, 2000.

Jimenez, J. L., Canagaratna, M. R., Donahue, N. M., Prevot, A. S. H., Zhang, Q., Kroll, J. H., DeCarlo, P. F., Allan, J. D., Coe, H., Ng, N. L., Aiken, A. C., Docherty, K. S., Ulbrich, I. M., Grieshop, A. P., Robinson, A. L., Duplissy, J., Smith, J. D., Wilson, K. R., Lanz, V. A., Hueglin, C., Sun, Y. L., Tian, J., Laaksonen, A., Raatikainen, T., Rautiainen, J., Vaattovaara, P., Ehn, M., Kulmala, M., Tomlinson, J. M., Collins, D. R., Cubison, M. J., Dunlea, E. J., Huffman, J. A., Onasch, T. B., Alfarra, M. R., Williams, P. I., Bower, K., Kondo, Y., Schneider, J., Drewnick, F., Borrmann, S., Weimer, S., Demerjian, K., Salcedo, D., Cottrell, L., Griffin, R., Takami, A., Miyoshi, T., Hatakeyama, S., Shimono, A., Sun, J. Y., Zhang, Y. M., Dzepina, K., Kimmel, J. R., Sueper, D., Jayne, J. T., Herndon, S. C., Trimborn, A. M., Williams, L. R., Wood, E. C., Middlebrook, A. M., Kolb, C. E., Baltensperger, U., and Worsnop, D. R.: Evolution of organic aerosols in the atmosphere, Science, 326, 1525-1529, 2009.

Joutsensaari, J., Vaattovaara, P., Vesterinen, M., Hämeri, K., and Laaksonen, A.: A novel tandem differential mobility analyzer with organic vapor treatment of aerosol particles, Atmos. Chem. Phys., 1, 51-60, doi:10.5194/acp-1-51-2001, 2001.

Joutsensaari, J., Toivonen, T., Vaattovaara, P., Vesterinen, M., Vepsäläinen, J., and Laaksonen, A.: Time-resolved growth behavior of acid aerosols in ethanol vapor with a tandem-DMA technique, J. Aerosol Sci., 35, 851-867, 2004.

Joutsensaari, J., Loivamäki, M., Vuorinen, T., Miettinen, P., Nerg, A.-M., Holopainen, J. K., and Laaksonen, A.: Nanoparticle formation by ozonolysis of inducible plant volatiles, Atmos. Chem. Phys., 5, 1489-1495, doi:10.5194/acp-5-1489-2005, 2005.

Kalberer, M., Paulsen, D., Sax, M., Steinbacher, M., Dommen, J., Prevot, A. S. H., Fisseha, R., Weingartner, E., Frankevich, V., Zenobi, R., and Baltensperger, U.: Identification of polymers as major components of atmospheric organic aerosols, Science, 303, 1659-1662, 2004.

Keywood, M. D., Kroll, J. H., Varutbangkul, V., Bahreini, R., Flagan, R. C., and Seinfeld, J. H.: Secondary organic aerosol formation from cyclohexene ozonolysis: Effect of $\mathrm{OH}$ scavenger and the role of radical chemistry, Environ. Sci. Technol., 38, 33433350, 2004.

Kleindienst, T. E., Edney, E. O., Lewandowski, M., Offenberg, J. H., and Jaoui, M.: Secondary organic carbon and aerosol yields from the irradiations of isoprene and alpha-pinene in the presence of $\mathrm{NO}_{\mathrm{x}}$ and $\mathrm{SO}_{2}$, Environ. Sci. Technol., 40, 3807-3812, 2006.

Kiendler-Scharr, A., Zhang, Q., Hohaus, T., Kleist, E., Mensan, A., Mentel, Th.F., Spindler, C., Uerlings, R., Tillmann, R., and Wildt, J.: Aerosol mass spectrometric features of biogenic SOA: Observations from a plant chamber and in rural atmospheric environments, Environ. Sci. Technol., 43, 8166-8172, 2009a.

Kiendler-Scharr, A., Wildt, J., Dal Maso, M., Hohaus, T., Kleist, E., Mentel, Th. F., Tillmann, R., Uerlings, R., Schurr, U., and Wahner, A.: New particle formation in forests inhibited by isoprene emissions, Nature, 461, 381-384, 2009b.

Kroll, J. H. and Seinfeld, J. H.: Chemistry of secondary organic aerosol: Formation and evolution of low-volatility organics in the atmosphere, Atmos. Environ., 42, 3593-3624, 2008.

Kroll, J. H., Chan, A. W. H., Ng, N. L., Flagan, R. C., and Seinfeld, J. H.: Reactions of semivolatile organics and their effects on secondary organic aerosol formation, Environ. Sci. Technol., 41, 3545-3550, 2007.

Lambe, A. T., Zhang, J. Y., Sage, A. M., and Donahue, N. M.: Controlled $\mathrm{OH}$ radical production via Ozone-alkene reactions for use in aerosol aging studies, Environ. Sci. Technol., 41, 23572363, 2007.

Lang-Yona, N., Rudich, Y., Mentel, Th. F., Bohne, A., Buchholz, A., Kiendler-Scharr, A., Kleist, E., Spindler, C., Tillmann, R., and Wildt, J.: The chemical and microphysical properties of secondary organic aerosols from Holm Oak emissions, Atmos. Chem. Phys., 10, 7253-7265, doi:10.5194/acp-10-7253-2010, 2010.

Lindinger, W., Hansel, A., and Jordan, A.: Proton-transfer-reaction mass spectrometry (PTR-MS): on-line monitoring of volatile organic compounds at pptv levels, Chemical Society Reviews, 27, 347-354, 1998.

Manninen, A.-M., Vuorinen, M., and Holopainen, J. K.: Variation in growth, chemical defense and herbivore resistance in Scots pine provenances, J. Chem. Ecol., 24, 1315-1331, 1998.

McFiggans, G., Coe, H., Burgess, R., Allan, J., Cubison, M., Alfarra, M. R., Saunders, R., Saiz-Lopez, A., Plane, J. M. C., Wevill, D., Carpenter, L., Rickard, A. R., and Monks, P. S.: Direct evidence for coastal iodine particles from Laminaria macroalgae - linkage to emissions of molecular iodine, Atmos. Chem. Phys., 4, 701-713, doi:10.5194/acp-4-701-2004, 2004.

McGraw, R.: A corresponding states correlation of the homogeneous nucleation thresholds of supercooled vapors, J. Chem. Phys., 75, 5514-5521, 1981.

Mentel, Th. F., Wildt, J., Kiendler-Scharr, A., Kleist, E., Tillmann, R., Dal Maso, M., Fisseha, R., Hohaus, Th., Spahn, H., Uerlings, R., Wegener, R., Griffiths, P. T., Dinar, E., Rudich, Y., and Wahner, A.: Photochemical production of aerosols from real plant emissions, Atmos. Chem. Phys., 9, 4387-4406, doi:10.5194/acp9-4387-2009, 2009.

Ng, N. L., Kroll, J. H., Keywood, M. D., Bahreini, R., Varutbangkul, V., Flagan, R. C., and Seinfeld, J. H.: Contribution of first- versus second-generation products to secondary organic aerosols formed in the oxidation of biogenic hydrocarbons, Environ. Sci. Technol., 40, 2283-2297, 2006.

Ng, N. L., Chhabra, P. S., Chan, A. W. H., Surratt, J. D., Kroll, J H., Kwan, A. J., McCabe, D. C., Wennberg, P. O., Sorooshian, A., Murphy, S. M., Dalleska, N. F., Flagan, R. C., and Seinfeld, J. H.: Effect of $\mathrm{NO}_{\mathrm{x}}$ level on secondary organic aerosol (SOA) formation from the photooxidation of terpenes, Atmos. Chem. Phys., 7, 5159-5174, doi:10.5194/acp-7-5159-2007, 2007.

Ng, N. L., Canagaratna, M. R., Zhang, Q., Jimenez, J. L., Tian, J., Ulbrich, I. M., Kroll, J. H., Docherty, K. S., Chhabra, P. S., Bahreini, R., Murphy, S. M., Seinfeld, J. H., Hildebrandt, L., Donahue, N. M., DeCarlo, P. F., Lanz, V. A., Prévôt, A. S. H., Dinar, E., Rudich, Y., and Worsnop, D. R.: Organic aerosol components observed in Northern Hemispheric datasets from Aerosol Mass Spectrometry, Atmos. Chem. Phys., 10, 46254641, doi:10.5194/acp-10-4625-2010, 2010.

Northcross, A. L. and Jang, M.: Heterogeneous SOA yield from ozonolysis of monoterpenes in the presence of inorganic acid, Atmos. Environ., 41, 1483-1493, 2007. 
Odum, J. R., Hoffmann, T., Bowman, F., Collins, D., Flagan, R. C., and Seinfeld, J. H.: Gas/Particle partitioning and secondary organic aerosol yields, Environ. Sci. Technol., 30, 2580-2585, 1996.

Pankow, J. F.: An absorption model of gas/particles partitioning of organic compounds in the atmosphere, Atmos. Environ., 28, 185-188, 1994a.

Pankow, J. F.: An absorption model of the gas/aerosol partitioning involved in the formation of secondary organic aerosol, Atmos. Environ., 28, 189-193, 1994b.

Pathak, R. K., Stanier, C. O., Donahue N. M., and Pandis, S. N.: Ozonolysis of $\alpha$-pinene at atmospherically relevant concentrations: Temperature dependence of aerosol mass fractions (yields), J. Geophys. Res., 112, D03201, doi:10.1029/2006JD007436, 2007.

Paulsen, D., Weingartner, E., Alfarra, M. R., and Baltensperger, U.: Volatility measurements of photochemically and nebulizergenerated organic aerosol particles, J. Aerosol Sci., 37, 10251051, 2006.

Pinto, D. M., Tiiva, P., Miettinen, P., Joutsensaari, J., Kokkola, H., Nerg, A.-M., Laaksonen, A., and Holopainen, J. K.: The effects of increasing atmospheric ozone on biogenic monoterpene profiles and the formation of secondary aerosols, Atmos. Environ., 41, 4877-4887, 2007.

Presto, A. A. and Donahue, N. M.: Secondary organic aerosol production from terpene ozonolysis. 2. Effect of $\mathrm{NO}_{\mathrm{x}}$ concentration, Environ. Sci. Technol., 39, 7046-7054, 2005.

Presto, A. A. and Donahue, N. M.: Investigation of alpha-pinene plus ozone secondary organic aerosol formation at low total aerosol mass, Environ. Sci. Technol., 40, 3539-3543, 2006.

Presto, A. A., Hartz, K. E. H., and Donahue, N. M.: Secondary organic aerosol production from terpene ozonolysis. 1. Effect of UV radiation, Environ. Sci. Technol., 39, 7036-7045, 2005.

Raatikainen, T., Vaattovaara, P., Tiitta, P., Miettinen, P., Rautiainen, J., Ehn, M., Kulmala, M., Laaksonen, A., and Worsnop, D. R.: Physicochemical properties and origin of organic groups detected in boreal forest using an aerosol mass spectrometer, Atmos. Chem. Phys., 10, 2063-2077, doi:10.5194/acp-10-20632010, 2010.

Räisänen, T., Ryyppö, A., and Kellomäki, S.: Monoterpene emission of a boreal Scots pine (Pinus sylvestris L.) forest, Agr. Forest Meteorol., 149, 808-819, 2009.

Saathoff, H., Naumann, K.-H., Möhler, O., Jonsson, Å. M., Hallquist, M., Kiendler-Scharr, A., Mentel, Th. F., Tillmann, R., and Schurath, U.: Temperature dependence of yields of secondary organic aerosols from the ozonolysis of $\alpha$-pinene and limonene, Atmos. Chem. Phys., 9, 1551-1577, doi:10.5194/acp-9-15512009, 2009.

Seinfeld, J. H., Erdakos, G. B., Asher, W. E., and Pankow, J. F.: Modeling the formation of secondary organic aerosol (SOA). 2. The predicted effects of relative humidity on aerosol formation in the alpha-pinene-, beta-pinene-, sabinene-, Delta(3)-Carene, and cyclohexene-ozone systems, Environ. Sci. Technol., 35, 1806-1817, 2001.

Shilling, J. E., Chen, Q., King, S. M., Rosenoern, T., Kroll, J. H., Worsnop, D. R., McKinney, K. A., and Martin, S. T.: Particle mass yield in secondary organic aerosol formed by the dark ozonolysis of $\alpha$-pinene, Atmos. Chem. Phys., 8, 2073-2088, doi:10.5194/acp-8-2073-2008, 2008.
Shilling, J. E., Chen, Q., King, S. M., Rosenoern, T., Kroll, J. H., Worsnop, D. R., DeCarlo, P. F., Aiken, A. C., Sueper, D., Jimenez, J. L., and Martin, S. T.: Loading-dependent elemental composition of a-pinene SOA particles, Atmos. Chem. Phys., 9, 771-782, doi:10.5194/acp-9-771-2009, 2009.

Slowik, J. G., Stroud, C., Bottenheim, J. W., Brickell, P. C., Chang, R. Y.-W., Liggio, J., Makar, P. A., Martin, R. V., Moran, M. D., Shantz, N. C., Sjostedt, S. J., van Donkelaar, A., Vlasenko, A., Wiebe, H. A., Xia, A. G., Zhang, J., Leaitch, W. R., and Abbatt, J. P. D.: Characterization of a large biogenic secondary organic aerosol event from eastern Canadian forests, Atmos. Chem. Phys., 10, 2825-2845, doi:10.5194/acp-10-2825-2010, 2010.

Tiitta, P., Miettinen, P., Vaattovaara, P., Joutsensaari, J., Petäjä, T., Virtanen, A., Raatikainen, T., Aalto, P., Portin, H., Romakkaniemi, S., Kokkola, H., Lehtinen, K. E. J., Kulmala, M., and Laaksonen, A.: Roadside aerosol study using hygroscopic, organic and volatility TDMAs: Characterization and mixing state, Atmos. Environ., 44, 976-986, 2010.

Tunved, P., Hansson, H.-C., Kerminen, V.-M., Ström, J., Dal Maso, M., Lihavainen, H., Viisanen, Y., Aalto, P. P., Komppula, M., and Kulmala, M.: High natural aerosol loading over boreal forests, Science, 312, 261-263, 2006a.

Tunved, P., Korhonen, H., Ström, J., Hansson, H.-C.,Lehtinen, K. E. J., and Kulmala, M.: Is nucleation capable of explaining observed aerosol integral number during southerly transport over Scandinavia, Tellus, 58B, 129-140, 2006b.

Vaattovaara, P., Petäjä, T., Joutsensaari, J., Miettinen, P., Zaprudin, B., Kortelainen, A., Heijari, J., Yli-Pirilä, P., Aalto, P., Worsnop, D. R., and Laaksonen, A.: The evolution of nucleation- and Aitken-mode particle compositions in a boreal forest environment during clean and pollution-affected new-particle formation events, Boreal Environ. Res., 14, 662-682, 2009.

VanReken, T. M., Greenberg, J. P., Harley, P. C., Guenther, A. B., and Smith, J. N.: Direct measurement of particle formation and growth from the oxidation of biogenic emissions, Atmos. Chem. Phys., 6, 4403-4413, doi:10.5194/acp-6-4403-2006, 2006.

Virtanen, A., Joutsensaari, J., Koop, T., Kannosto, J., Yli-Pirilä, P., Leskinen, J., Mäkelä, J. M., Holopainen, J. K., Pöschl, U., Kulmala, M., Worsnop, D. R., and Laaksonen, A.: An amorphous solid state of biogenic secondary organic aerosol particles, Nature, 467, 824-827, doi:10.1038/nature09455, 2010.

von Hessberg, C., von Hessberg, P., Pöschl, U., Bilde, M., Nielsen, O. J., and Moortgat, G. K.: Temperature and humidity dependence of secondary organic aerosol yield from the ozonolysis of $\beta$-pinene, Atmos. Chem. Phys., 9, 3583-3599, doi:10.5194/acp9-3583-2009, 2009.

Vuorinen, T., Nerg, A.-M., Ibrahim, M. A., Reddy, G. V. P., and Holopainen, J. K.: Emission of Plutella xylostella-induced compounds from cabbages grown at elevated $\mathrm{CO}_{2}$ and orientation behavior of the natural enemies, Plant Physiol., 135, 1984-1992, 2004.

Zhang, Q., Stanier, C. O., Canagaratna, M. R., Jayne, J. T., Worsnop, D. R., Pandis, S. N., and Jimenez, J. L.: Insights into the chemistry of new particle formation and growth events in Pittsburgh based on Aerosol Mass Spectrometry, Environ. Sci. Technol., 38, 4797-4809, 2004. 